\title{
The rights of minority shareholders in French and German public companies
}

\author{
by Frank Wooldridge
}

\section{INTRODUCTION}

$\mathrm{T}$ The present article cannot give an entirely comprehensive view of the topics which it considers, and will necessarily restrict itself to a treatment of their salient features. At present, there is no Commission proposal aiming at the harmonisation of the law concerning minority protection in public companies, although such protection has apparently frequently been the topic of books, articles and postgraduate theses in different jurisdictions. Although the Commission's recent Communication on Modernising Company Law mentions the need for shareholder democracy, it does not contain any definite new proposals concering minority protection.

\section{THE POSITION IN FRANCE}

\section{Minority rights and general meetings}

Meetings of French societés anonymes (SAs or public companies) may be convened by the board of directors, or the supervisory board. If the directors or supervisory board fail to call a meeting, it may be called by the statutory auditors, or the liquidators if the company is in liquidation. Furthermore, in case of urgency any interested party or one or more shareholders holding at least onetenth of the company's issued capital may apply to the President of the Commercial Court to appoint a special representative who is empowered to call a meeting (Commercial Code, Article L225-103).

The person calling the meeting is responsible for fixing its agenda (Article L225-105, ibid). However, shareholders holding at least $5 \%$ of the issued capital are empowered by Article L225-105(2) of the Commercial Code to require resolutions prepared by them to be placed on the agenda of a meeting. Article 128 of Decree No. 67-236 of 23 March 1967, as amended, contains special rules governing the required holdings when the company's capital exceeds certain amounts.

\section{Minority rights in other situations}

The types of shareholders' rights

Shareholders, acting individually or collectively, may exercise certain rights which are not immediately associated with general meetings. Certain of these rights may be exercised by individual shareholders, whilst others may only be exercised by a shareholder or shareholders possessing $10 \%$ or more of the company's capital. Furthermore, certain special rules govern the minimum percentage of shareholders who can require (if the articles so provide) that certain actions may be taken in the event of failure to disclose relevant changes in the accounts of shares held by another shareholder or shareholders in conformity with the provisions of the company's articles (see Article L233-7, paragraphs 5 and 6 of the Commercial Code). The relevant percentage of shareholder(s) consists of one or more persons holding a fraction of the capital or voting rights in the company at least equal to the smallest fraction of capital which must be declared according to the articles (as opposed to the legal rules set out in Article L233-7, paragraph 1). This amount may not exceed $5 \%$ of the capital. The holders of such an amount of the company's capital, or of a larger one may require that any shareholder who has failed to fulfil his obligation of disclosure shall be deprived of his excess voting rights for two years after the regularisation of the position (Article L233-7, paragraph 6).

However, when a company is listed, individual shareholders the Stock Exchange Commission and the public prosecutor have the right to request the Commercial Court that any shareholder who has failed to disclose its shareholdings shall lose all or part of his voting rights for a period not exceeding five years. This rule is quite independent of anything expressed in the company's articles (Article L233-14, paragraph 4).

\section{Other rights of an individual nature}

Shareholders in French public companies have significant individual rights to obtain access to certain documents and information associated with the general meetings held during the last three financial years. These rights may be exercised at any time and are granted by Articles L225-115 to L225-117 at the Commercial Code (see Le Gall, French Company Law, 2nd ed, Longmans, 1992, pp.143-44). They may also be exercised by the joint owners or persons having a usufruct over shares (Article L2 15-118). 
The relevant documents include the inventory, the annual financial statements, consolidated accounts (if any), a list of the existing directors or members of the supervisory and executive boards, as well as that of the statutory auditors (Commissaires aux comptes) (Article L225-115, Nos 1 and 2). Information must also be made available concerning candidates for election to the board or boards of the company, and individual shareholders are also entitled to particulars of resolutions proposed at meeting together with the attendance sheets (Article L225-115, No. 3 and Article L225-116). Furthermore, individual shareholders are entitled to a statement, certified by the statutory auditors, of the total amount of remuneration paid to the five highest paid employees if the company has no more than 200 employees, and to the 10 highest paid employees if the number of employees exceeds 200 (Article L225-115, No. 4). Particulars, certified by the statutory auditors, must be given of taxable amounts earned by the company, and of registered shares held by nominees (Article L225-115, No. 5). Individual shareholders are also entitled to see the minutes of shareholders' meetings held during the last three financial years (Article L225-117). The above rights appear very extensive, but the extent to which they are exercised in practice obviously depends on the degree of sophistication of the shareholders and the extent to which they are conscious of their rights.

Individual shareholders are able to bring derivative actions in the name of the public company against its directors or the members of its executive or supervisory boards in respect of damage suffered by it (Article L225-252). They may also bring a direct action against the company, its directors, majority shareholders or statutory auditors if they believe they have suffered personal damages which is different from that suffered by the company. Such actions may be based upon the general provisions of Article 1382 of the Civil Code concerning torts (delicts).

Procedures which allow several shareholders to appoint one or more common representatives from amongst themselves to commence an action in their name are available both in the case of personal and derivative actions (Decree No. 67-236 of 23 July 1967, Articles 199 and 200). Where derivative suits are concerned, the procedure is only available to the holders of at least the same percentage of the company's capital which is empowered to propose resolutions at shareholders' meetings (Article 200, ibid).

The introduction of some kind of statutory derivative action may eventually take place in the United Kingdom as was suggested by the Law Commission in its 1997 paper, Shareholder Remedies (Com 3769) it was intended that the new procedure would replace the existing common law one. The Law Commission's proposal regarding the ratification of breaches of their duties by the directors has received some criticism. There is no remedy available to minority shareholders in France or other civil law countries corresponding to that granted under sections 459-461 of the Companies Act 1985. As in the United Kingdom (No. 00596 of 1986) [1987] BCLC 133) where the normal operation of the company is prevented by serious difficulties, the court may appoint a temporary manager on the petition of an individual shareholder. Such a person is called a receiver in the United Kingdom. In both this country and France, the relevant remedy is not readily granted.

\section{Rights of shareholders holding at least $10 \%$ of the share capital}

As in Germany, French shareholders individually or collectively holding at least $10 \%$ of share capital of a public company have certain rights. These rights less frequently consist of the ability to successfully object to a particular measure than is the case in Germany. However, a minority consist of the holders of more than one third of the votes present or represented can block an extraordinary resolution (Commercial Code, Article L225-96, paragraph. 113).

The minority of shareholders mentioned at the beginning of the above paragraph is empowered by Article L235-232 to submit written questions twice a year to the chairman of the managing or executive board concerning any matter which might compromise the continuance of the company's operations. The response to these questions must be given within a period of one month and be communicated to the statutory auditors. The same minority also has the important power granted them by Article L235-231 of petitioning the court requiring it to appoint one or more experts charged with the task of reporting on one or more management decisions. The relevant minority of shareholders share this power with the works committee (comité d'enterprise), the Stock Exchange Commission (Commission des Operations de Bourse) in the case of listed companies, and the public prosecutors). The present power has been made much use of in practice, and there are a number of relevant court decisions concerning its exercise. The Commission's recent Communication on Modernising Company Law mentions the proposal of the High Level Group that shareholders in EC public companies having a specified percentage of the share capital should have the right to request a special investigation.

By Article L225-230, one or more shareholders representing at least one tenth of the company's capital may object to the appointment of statutory auditors by the general meeting. According to Article 188 of Decree No. 67-236 of 23 July 1967, such an objection must be made within 30 days of the appointment of such auditors. Article L225-233 empowers the same majority of shareholders, as well as the managing or executive board and the works committee, to request the Commercial Court to dismiss any statutory auditor who does not perform his tasks adequately, or who is prevented from fulfilling them by reasons of illness or any other cause. Finally, when the public company is controlled by another undertaking 
which includes it in the consolidated accounts, thereby making it exempt from the preparation of such accounts, the stipulated majority of shareholders is enabled by Article L233-17 to deny it the possibility of such an exemption.

\section{THE POSITION IN GERMANY}

Minority rights are generally treated under German law as belonging to the holders of a specific percentage of the share capital. However it may be noted that individual shareholders in a Germany public company (Aktiengesellschaft) are given the right to such information as they require to properly evaluate agenda item (paragraph 131, German Aktiengesetz). This right may only be denied them in certain specified circumstances, for example where its exercise would cause material damage to the company. The court may decide whether such information must be provided (paragraph 132, German Aktiengesetz).

\section{Minority protection and general meetings}

The holders of $5 \%$ of a public company's share capital may request the calling of a special shareholders' meeting in writing stating its purpose and the reason for it (paragraph 122(1), AktG). Shareholders holding 5\% of the share capital or an amount equivalent (the German text uses the phrase anteiligen Betrag which means proportionate amount: this wording appears to take account of no par value shares (Stückaktien)) to 500,000 euros may require the inclusion of a specific item on the agenda (paragraph 122(2) AktG). If the management board fails to comply with one of the requests mentioned in the present paragraph, the court may authorise the relevant shareholders to call a meeting or to publish the relevant items (paragraph 123(3) AktG).

\section{Minority rights in other situations}

The rules of German law are somewhat detailed and have undergone some amendments to recent years. Certain rights are given to a minority holding 5\% of the company's capital or an amount thereof equivalent to 500,000 euros: these include the right to petition the court in particular circumstances, for example under paragraphs 254(2) (actions to set aside a resolution on the appropriation of distributable profits), 258(2) (appointment of special auditors by reason of material undervaluations in the accounts) and 265(3) AktG (appointment or removal of liquidators)

A $10 \%$ minority is empowered to prevent a waiver or compromise at various claims which a company may have against members of the boards of the company or other persons, for example those who exert an influence on the company contrary to the requirements of paragraph 117(1) AktG. The relevant legal provisions are set out in paragraphs 50, 53, 93(4), 116 and 117(4) AktG. Thus, as a further example, paragraph $50 \mathrm{AktG}$ provides that claims against the founders of the company and the boards thereof in respect of the incorporation of the company may only be waived or compromised if the shareholders' meeting so consents and no minority whose aggregate holding is equal to or exceeds $10 \%$ of the share capital records an objection in the minutes.

The same $10 \%$ minority (which must in these cases consist of shareholders represented at the passing of the resolution) may also block a waiver or settlement of claims which a controlled company has against the controlling one (see paragraphs 309(3), 310(4), 317(4), 318(4) and 323(1) AktG). The latter rules are applicable to contractual groups de facto groups and integrated ones. According to paragraph 147(1) AktG, a 10\% minority that has held its shares for at least three months prior to the relevant meeting may require the enforcement of claims by the company for compensation for damages which have arisen in connection with the formation or management of the company, or in respect of the improper use of influence on it. Any such claim must be brought within six months of the date of the meeting when the request was made. A recent change in the law, which should enhance the position of the minority, has made it possible for the court to appoint special representatives upon the motion of shareholders whose total shareholdings exceeds $5 \%$ of the share capital, or an amount thereof equivalent to 500,000 euros. The court may so act if there are facts which justify the serious suspicion that the company suffered a loss through dishonest conduct, or a gross violation of the law or the articles. The court appointed representatives may assert the claim for compensation in appropriate circumstances (paragraph 147(3) AktG).

A minority holding $10 \%$ or more of the share capital or an amount equivalent to one million euros may petition the court for the appointment of a special auditor when the shareholders' meeting has failed to make such an appointment. Facts must exist which give rise to the suspicion that improprieties or serious breaches of the law have occurred in connection with any matter relating to the formation of the company or the management of its business during the past five years (paragraph 143(2) AktG). A similar minority may require separate resolutions to be passed on certain or all the members of the boards concerning their discharge from responsibility (paragraph 120(1) AktG). The latter minority is also entitled to make application to the court for the dismissal of members of the supervisory board who have been appointed by certain shareholders, when there is good reason for $\mathrm{s}$ doing (paragraph 103(2) AktG).

The holders of more than $25 \%$ of the share capital of a public company are sometimes referred to as a blacking minority (Schachtelminorität), because they are able to block those company resolutions which have to be passed by a $75 \%$ majority, e.g. resolutions for the alteration of the articles. However, some commentators protest that such shareholders should not be treated as having a minority right. 


\section{CONCLUDING REMARKS}

There does not seem to be very much in common between the relevant rules of French and German law except, to some extent insofar as they concern the calling of meetings, and derivative actions. Thus German law does not contain any provisions permitting a minority to object to the appointment of auditors, or to request the court to deprive shareholders who have been guilty of nondisclosure of their holdings, of their voting rights. Despite the provisions of paragraphs 131 and 132 AktG, German shareholders in public companies do not appear to enjoy the extensive rights to information and documents enjoyed by their French counterparts. Shareholders in French public companies which are listed have still more extensive rights.
If the draft Fifth Directive on Employee Participation and Company Structure had been enacted, this would have resulted in the establishment of common rules for derivative actions in the EC Member States (see Articles 14 and 16 of the 1972 proposal). Such a development now seems unlikely, as owing to political opposition, work on the draft Fifth Directive has now been abandoned. This development should not deter the enactment of substantive rules governing the derivative action in states in which such rules do not exist. Such rules should, it is submitted be applicable to certain situations where directors have been negligent, as well as to breaches of their statutory and other duties. (1)

Frank Wooldridge

\title{
Reinforcing territorial regimes: Uti possidetis and the right to self-determination in modern international law
}

\author{
by Steve Allen and Joshua Castellino
}

\section{INTRODUCTION}

A lthough the doctrine of uti possidetis finds its origins in the jus civile of Roman law, it was transposed into international law to facilitate the creation of new states during the decolonisation of Latin America and subsequently Africa. In its modern form the doctrine provides 'that new States will come to independence with the same boundaries they had when they were administrative units within the territory or territories of a colonial power' (Shaw, 'The Heritage of States: The Principle of Uti Possidetis Juris Today', 67 BYIL, 1996, 76, 97). For present purposes, the utility of uti possidetis lies in the fact that it provides an excellent illustration of the tension existing within modern international law between the evolution of the right to self-determination and the entitlement of states to protect their territorial integrity and retain exclusive jurisdiction in domestic matters.

By way of introduction, the article will briefly discuss the right to self-determination and the problems it poses for the international state system. Against the backdrop of African decolonisation it will then examine the ramifications of uti possidetis for self-determination in an attempt to decipher the key priorities of the current international system. Finally, the article will seek to assess the validity of the recent extension of uti possidetis to noncolonial situations and the resonance of this development for modern international law in general.

\section{Self-determination and existing territorial regimes}

One theory of self-determination considers the state to be merely the political manifestation of its constituent nation (or people). This interpretation allows a nation to recreate its political form in the light of national developments to ensure that the political unit (the State) and the nation remain congruent. Underpinning this approach is the claim that a nation or people of a given territory have the right to decide the nature and form of their own political identity. However in practice the 